\title{
The Rhetoric of Technology as a Rhetorical Technology ${ }^{1}$
}

John Lynch

Department of Communication, University of Cincinnati

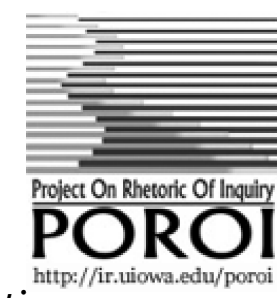

Cincinnati, OH USA

William J. Kinsella

Department of Communication, North Carolina State University Raleigh, NC USA

Poroi 9,1 (April 2013)

What does it mean to study the rhetoric of technology? While such a question appears almost facile, offering a substantive answer to the question is challenging. There are as many definitions of "rhetoric" as there are scholars of it, leading to the risk of incommensurable definitions (Harris, 2005; Heidebaugh, 2001). Similar risks exist with "technology," which can refer to discrete artifacts, the systems and practices surrounding the use of said artifacts, and the application of scientific principles to practice (i.e., engineering). Our discussion focused on this and similar "first principles" questions so as to distinguish what a rhetoric of technology would study and how that study would differ from scholarship in media ecology, human-computer interaction, mass communication, cultural studies, social psychology, and a host of other fields.

At its root, we find that rhetoric and technology are both defined in relation to the concept of "invention" (Basalla, 1988; Simons, 1990). Neither rhetoric nor technology represent a creation ex nihilo; rather, each results from the gathering and deployment of existing resources, whether these are the scientific principles or material foundations that become the basis for a specific device or the ideas and arguments that form the basis for a finished discourse. Although grounding rhetoric generally and the rhetoric of technology specifically in "invention" partly addresses concerns about the globalization of rhetoric (Gaonkar, 1996), foregrounding invention locates rhetoric (as well as technology) in a liminal space: The space of technology is that tenuous, hard to map territory between the novel and familiar and the natural and the social, just as the space for the rhetoric of technology lies betwixt and between multiple disciplinary formations, both within rhetoric and across the humanities (see Bazerman, 1998).

\footnotetext{
${ }^{1}$ We would like to thank Bill White and David Clanaugh for their contributions to the roundtable discussion.
} 


\section{The Liminality of "Technology"}

Technology occupies liminal zones: between the novel and the familiar, between technologies open to inspection and those opaquely "blackboxed," between the public domain of "natural" phenomena and the patentable domain of "technological" phenomena (e.g., Carolan, 2008). Technology is understood as discrete objects and as a way of life. As discrete objects, technological artifacts have a life-cycle: the move from the stage of "potential" technology-an application of scientific principles and findings being developed into a prototype-to the settled, blackboxed technology represented post facto by signifiers such as patents (Besel, 2011; Latour, 1996; Scott, 2003, chapter 7; Toscano, 2012). The development of technology has been a primary site for rhetorical studies of technology (Dyehouse, 2007; Miller, 1994).

In its manifestation as discrete objects for use, technology has been cited as the "strongest possible case" for asserting or deconstructing the principle of recalcitrant materiality (Woolgar, 1991). Science studies scholars such as Donna Haraway (1991), Don Ihde (1983), Bruno Latour (1988), and Andrew Pickering (1984) have grappled inventively with the intersections of science, technology and materiality. Ihde's "postphenomenology," and notions of "hybridity" associated with actornetwork theory (e.g., Callon, 2002; Ihde \& Selinger, 2003; Latour, 1996) provide resources for exploring epistemological questions linking materiality, technology, and human agency. At times, rhetoricians have taken up the issue of materiality (e.g., Condit, 2008). These rhetorical approaches sometimes invoke the theories of science studies (e.g., Stormer, 2004), especially Latour's concept of blackboxing, but scholars in the field disagree about the value of such approaches for rhetorical analyses of science and technology. For example, the concept of the black box often invokes a sense of technological determinism where the position supported by the greatest number of technological tools wins (Gross, 1990).

Technology is also a way of life or engenders ways of life. Winner (1986) argues that nuclear energy technologies demand top-down social organization. Banks (2006, 2011) addresses the political dimensions of technology through a rhetorical lens, linking issues of race, technological access, and inventive performance, while Bazerman's (1999) study of Edison's incandescent light and its placement as an everyday technology highlights the profligacy of rhetorics of technology and how that profligacy - the ability to circulate through and transform diverse publics ranging from business and the courts (i.e., patents) to local politics, journalism, consumers, and a general public-is necessary. In other words, in order to succeed, a technology and a rhetoric of technology will involve the transformation of multiple aspects of our social milieu.

Yet, alongside this capacity for transformation, rhetorics of particular technologies often serve as terministic screens (Burke, 1966). Some aspects of technological assemblages receive attention, while others are displaced, often with political effects (Sauer, 2003; Winner, 1986). Our discussion addressed the controversial process known as sulfide mining, where a focus on acid pollutants has been accompanied by little record- 
keeping regarding other types of pollutants, especially arsenic and manganese. This industrial example ironically illustrates technology as a way of life in that entire social and regulatory structures are premised on the oversight of a large set of material problems.

A rhetoric of technology can help illuminate these various spaces and practices. Yet rhetoric is also a liminal object, whose disciplinary location lies somewhere between media ecology, science studies, and communication studies.

\section{The Liminality of "Rhetoric"}

The second issue we considered was disciplinary liminality: How do rhetorical studies of technology relate to the rhetoric of science and medicine but also to media ecology, human-computer interaction, mass communication, cultural studies, social psychology, and a host of other fields? "Ontological gerrymandering” (Woolgar \& Pawluch, 1985) and rhetorical "boundary work" (Gieryn, 1983, 1995; Keränen, 2005; Taylor, 1991, 1994), pervade discussions about the relationships among "rhetoric of science," "rhetoric of technology," "rhetoric of science and technology," "rhetoric of science, technology and medicine," and the like.

Within the broader community of rhetorical and communication scholars, boundaries prevail. Rhetoric, game theory, media studies, cybernetics, and social psychology are all potential sites for the study of music or video games (e.g., Perron \& Wolf, 2008; Swalwell \& Wilson, 2008; Sterne, 2012). Assigning video games to any one field, a typical disciplinary move, occludes the inventive, scholarly possibilities afforded by the others. Beyond the fields of communication, scholars of politics, public policy, and legal and business deliberation all address technological issues and a wide range of questions related to technology, but often in incommensurable terms (Luhmann, 1998).

One place for meta-level rhetorical invention therefore lies in interrogating the boundaries across fields. The potential exists for the (re)convergence of fields through a focus on issues like posthumanism, technomedicine, and genomics. Contributors to the preconference emphasized that rhetorical approaches can make valuable contributions to the interdisciplinarity required to effectively address the complex, hybrid, and entangled phenomena of technology (see Condit, this issue; Prelli, this issue). Yet, this (re)convergence of fields has its risks. It is possible that military and security-state interests, global capitalism, etc., are propelling some of this convergence. For example, the military has moved from a nearly exclusive focus on nuclear weapons to concerns regarding bio-weapons (see Keränen, 2011; Scott, 2006). Moving forward in these spaces of potential interdisciplinary convergence will require rhetorical and ethical sensitivity to the issues and interests in play around any single issue.

\section{Conclusion}

Rhetorical studies of technology (or technologies) ideally encourage us to identify and reflect upon the moments of decision in technological 
development writ large. They ask us to examine the choices that we have made during the creation and dissemination of any given technology, which we can hopefully revise or redesign. As part of that reflexive process, we recognize how technology reconfigures society by creating new connections between disparate parts of our social world. When we allow our studies to be influenced by a technological determinism by assuming the givenness of a specific technology or social configuration, we fail to recognize the choices made in creating technology, the rhetorics that attend it, and the implications of those choices.

Another way to conceive of the choices made in shaping and speaking about technology is agency. In many ways, the inventional process at the heart of both rhetoric and technology is about agency- how we use, shape, and deny agency, etc. A rhetorical study of technology, then, is about how agency is reconfigured by the rhetorical strategies that attend the steps in inventing and disseminating a new technology. These studies allow us to see how technological determinism develops and persists, but perhaps most importantly, rhetorical studies of technology can help us resist the move to technological determinism. Additionally, rhetorical studies of technology can provide the intellectual space to consider the possibilities for agency that our words and tools have constructed. The best of the extant body of technology studies in rhetoric embody this agentic impulse, and it is this possibility with which we hope to (re)invent the field's future.

\section{References}

Banks, A. (2006). Race, rhetoric, and technology: Searching for higher ground. Mahwah, NJ: Erlbaum.

----. (2011). Digital griots: African-American rhetoric in a multimedia age. Carbondale, IL: Southern Illinois University Press.

Basalla, G. (1988). The evolution of technology. Cambridge, UK: Cambridge University Press.

Bazerman, C. (1998). The production of technology and the production of human meaning. Journal of Business and Technical Communication, 12(3), 381-387.

----. (1999). The languages of Edison's light. Cambridge, MA: MIT Press.

Besel, R. D. (2011). Opening the "black box" of climate change: Actornetwork theory and rhetorical practice in scientific controversies. Southern Journal of Communication, 76(2), 120-136.

Burke, K. (1966). Language as symbolic action. Berkeley, CA: University of California Press.

Callon, M. (2002). Writing and (re)writing devices as tools for managing complexity. In J. Law \& A. Mol (Eds.), Complexities in science, technology and medicine (pp. 191-217). Durham, NC: Duke University Press.

Carolan, M. S. (2008). From patent law to regulation: The ontological 
gerrymandering of biotechnology. Environmental Politics, 17(5), 749765 .

Condit, C. M. (2008). Race and genetics from a modal materialist perspective. Quarterly Journal of Speech, 94(4), 383-406.

Dyehouse, Jeremiah. (2007). Knowledge Consolidation Analysis: Towards a methodology for studying the role of argument in technology development. Written Communication, 24(2), 111-139.

Gaonkar, D. P. (1996). The idea of rhetoric in the rhetoric of science. In A. G. Gross \& W. M. Keith (Eds.), Rhetorical hermeneutics: Invention and interpretation in the age of science (pp. 25-88). Albany, NY: SUNY Press.

Gieryn, T. F. (1983). Boundary-work and the demarcation of science from non-science: strains and interests in the professional ideologies of scientists. American Sociological Review, 48, 781-795.

----. (1995). Boundaries of science. In S. Jasanoff, G. E. Markle, J. C. Petersen \& T. Pinch (Eds.), Handbook of science and technology studies (pp. 393-443). Thousand Oaks, CA: Sage.

Haraway, D. (1991), Simians, cyborgs, and women: The reinvention of nature. London, UK: Free Association Books.

Harris, R. A. (2005). Rhetoric and incommensurability. Anderson, SC: Parlor Press.

Heidebaugh, N. J. (2001). Judgment, rhetoric, and the problem of incommensurability. Columbia, SC: University of South Carolina Press.

Ihde, D. (1983). Existential technics. Albany, NY: SUNY Press.

Ihde, D., \& Selinger, E. (Eds.) (2003). Chasing technoscience: Matrix for materiality. Bloomington, IN: Indiana University Press.

Keränen, L. (2005). Mapping misconduct: Demarcating legitimate science from "fraud" in the B-o6 lumpetcomy controversy. Argumentation \& Advocacy, 42, 94-113.

----. (2011). Concocting viral apocalypse: Catastrophic risk and the production of bio(in)security. Western Journal of Communication, 75(5), 451-472.

Latour, B. (1988). The Pasteurization of France. Cambridge, MA: Harvard University Press.

----. (1996). Aramis, or the love of technology. Cambridge, MA: MIT Press.

Luhmann, N. (1998). Observations on modernity (W. Whobrey, Trans.). Stanford, CA: Stanford University Press.

Miller, C. R. (1994). Opportunity, opportunism, and progress: Kairos in the rhetoric of technology. Argumentation, 8, 81-96.

Perron, B., \& Wolf, M. J. P. (Eds.) (2008). The video game theory reader 2. New York: Routledge. 
Pickering, A. (1984), Constructing quarks: A sociological history of particle physics, Chicago, IL: University of Chicago Press.

Sauer, B. (2003). The rhetoric of risk: Technical documentation in hazardous environments. Mahwah, NJ: Erlbaum.

Scott, J. B. (2003). Risky rhetoric: AIDS and the cultural practices of HIV testing. Carbondale, IL: SIU Press.

----. (2006). Kairos as indeterminate risk management. Quarterly Journal of Speech, 92, 115-143.

Simons, H. W. (Ed.) (1990). The rhetorical turn: Invention and persuasion in the conduct of inquiry. Chicago, IL: The University of Chicago Press.

Sterne, J. (2012). MP3: The meaning of a format. Durham, NC: Duke University Press.

Stormer, N. (2004). Articulation: A working paper on rhetoric and taxis. Quarterly Journal of Speech, 9o(3), 257-284.

Swalwell, M., \& Wilson, J. (Eds.). (2008). The pleasures of computer gaming: Essays on cultural history, theory, and aesthetics. Jefferson, NC: MacFarland \& Company.

Taylor, C. A. (1991). Defining the scientific community: A rhetorical perspective on demarcation. Communication Monographs, 58, 402420.

----. (1994). Science as cultural practice: A rhetorical perspective. Technical Communication Quarterly, 3(1), 67-81.

Toscano, A. (2012). Marconi's wireless and the rhetoric of a new technology. London, UK: Springer.

Winner, L. (1986). Do artifacts have politics? In L. Winner, The whale and the reactor: A search for limits in an age of high technology (pp. 19-39). Chicago, IL: University of Chicago Press.

Woolgar, S. (1991). The turn to technology in social studies of science. Science, Technology, \& Human Values, 16(1), 20-50.

Woolgar, S., \& Pawluch, D. (1985). Ontological gerrymandering: The anatomy of social problems explanations. Social Problems, 32, 214227. 